\title{
The Role of Mass Media in Strangthening Intercultural Dialogue and Accord in Society
}

\author{
Olga Nikolaevna Savinova ${ }^{1}$ \\ ${ }^{1}$ Lobachevsky State University of Nizhni Novgorod-National Research University, Nizhny Novgorod, Russia \\ Correspondence: Olga Nikolaevna Savinova, Lobachevsky State University of Nizhni Novgorod-National \\ Research University, 603950, pr. Gagarina, 23, Nizhny Novgorod, Russia. E-mail: pr.unn.ru
}

Received: July 30, 2014 Accepted: September 30, 2014 Online Published: December 30, 2014

doi:10.5539/ass.v11n3p262 URL: http://dx.doi.org/10.5539/ass.v11n3p262

\begin{abstract}
Intercultural dialogue has an important role. It allows us to prevent ethnic, religious, linguistic and cultural divides. It enables us to move forward together, to deal with our different identities constructively and democratically on the basis of shared universal values. It emerged that no sphere should be exempt from engaging in intercultural dialogue - be it the neighborhood, the workplace, the education system and associated institutions, civil society and particularly the youth sector, the media, the arts world or the political arena.

The questions of the role of Mass Media in providing accord in ethno-cultural sphere and the responsibility of corporate journalist society for the realization of objections set to the press by the Strategy of national governmental politics of the RF are being discussed in the article.
\end{abstract}

Keywords: the Strategy of national governmental politics of the RF, intercultural dialogue, ethno-political discourse, tolerance

\section{Introduction}

The dichotomy "Mass Media and tolerance", "Mass Media and culture" is raising more and more questions nowadays and is a serious reason for contemplation about the mission and function of media in modern society, about the position of Mass Media in preserving original cultures and unity in transforming societies. In the situation of cross cultural and cross confessional confrontation becoming more and more poignant, the research of both foreign (Broun, 2006; Cottle, 2010; Lazarsfeld, 2010; White, Julie, \& Newcomber, 2012; Seow, 2005) and Russian (Malkova \& Tishkov, 2007; Mass Media in public sphere. The Materials of International theoretical and practical conference "Journalism 2010", 2011; Tolerance as a Factor of Counteraction against Xenophobia: Managing risks in the Society of Risk, 2011) authors are aimed at finding an answer to one of the most burning questions of today's society, which is what may be the basis of developing tolerance.

It is evident that tolerance in society cannot be imposed directively but as far as tolerance presupposes first and foremost a dialogue one of the tasks of Mass Media in civil society is exactly the setting of such a dialogue and making out the system of values of a tolerant type. This dialogue must always be held by government and society, state and the institutions of civil society and by different political forces in society itself. One more important factor of this dialogue is the unity of direct and reverse informational relations.

Mass Media reaches of fails to reach the settled purpose if it creates or fails to create the real informational picture of the world, if it serves reason but not instincts which ignite the discord. It is a task of the whole informational society and of Mass Media itself. It is natural, that Mass Media will always try to write about the negative but if it does not see all colours of social, political and cultural relations in society it works against the objections of strengthening intercultural accord.

The 2012 public discussion and the passage of the document basic for multinational and multi confessional Russian society - "The Strategies of State National Politics of Russian Federation" (The Present of the RF decree of 12.19.2012 N 1666 "To the strategy of state national policy of the Russian federation for the period up to 2025") - has become an important milestone in defining priorities to state institutions' affairs, the affairs of social organizations, of expert scientific society and Mass Media in the sphere of securing civil unity and cultural diversity development. 
In the enacted document it is also mentioned that state national politics is socially determined and has an inter-branch character. One of the objections of the Strategy in the sphere of culture and information is preserving original cultures, historical heritage and traditions of peoples of multinational Russia.

It is exactly in relaying upon Russian traditions of intercultural dialogue where lies the key to understanding and solving a lot of acute problems in ethno cultural sphere. The whole history of our country testifies to the cooperation and co-influence of cultures and traditions of different peoples, and these very historical traditions serve as a basis for the following development of intercultural dialogue.

Thus, the year 2012 was marked by an important date in the history of Russia, which is the $400^{\text {th }}$ anniversary of the feat of arms of militia led by Nizhniy Novgorod elder Kuzma Minin ad Moscow prince Dmitriy Pojarskiy, that saved Russia as a state and as a nationality. Side by side stood in this militia the representatives of different peoples and confessions united though by mutual agitation for the fate of the Motherland.

\section{Materials and Methods}

In the XVI-XVIII centuries there were a lot of families among Russian noblemen of Turkic origin. For example, the Yusupovs, the Tenishchevs, the Urusovs, who played an important role in political, military and cultural history of Russia.

The great Russian culture has always been attracted by the mysterious world of the East. Oriental subjects have attracted great Russian composers, artists, writers and poets, such as P. Chaykovskiy and A. Borodin, M. Vrubel and K. Brullov, A. Pushkin and M. Lermontov.

A Syrian scholar M. Sakur compared several suras from Koran with Pushkin's lines from "Podrozhaya Koranu" |"Resembling Koran"|. The author concludes that Pushkin, being the forefather of Russian literature, was interested in Koran, which touched him to the deepest of his heart.

These ideas of possible cultural synthesis were also reflected by Muslim intelligentsia. It is the activity of both Mirza Fatali Ahundov, a famous Azerbaijan enlightener and writer, and Ismail bey Gaspinskiy, Tatar and Crimean enlightener and the publisher of the first weekly newspaper in Turkic.

The History of Kazan, a universally recognized centre of Muslim culture, is the evidence of how Islam and Orthodoxy, secular and spiritual cultures, East and West have been closely connected throughout a thousand year history of the city.

The dialogue of cultures and traditional religions was laid primordially. It is based upon the similarity of moral and religious dogmas (in reference to the creation of the world, matters of war, attitude to nature, to family values, to matter, etc.), the development of the written language, cultural and literary connections.

A huge role in this intercultural dialogue belongs to the Russian language as to the language of international communication. Suffice it to say that, Cyrillic alphabet, created by the equal-to-the-apostle brothers Kirill and Mefodiy, great Slovenian enlighteners, became the basis of not only Slavonic languages but also of the Tatar language, the Bashkir language and many others.

Only due to the Russian language did the world learn the whole pleiad of names, among which are $\mathrm{Ch}$. Aytmanov, R. Gamzatov, D. Kugultinov, F. Alieva, N. Dumabadze and many others.

\section{Results}

Historic experience of mutual influence dictates the necessity of following cultural tradition and forming intercultural dialogue under new circumstances. Today it is even more important because of the developing processes of integration, because modern technologies and communicative possibilities "squeeze" time and space, because of Mass Media's developing new forms called to by modern world.

Printed press and Internet-media, which have entered every house, reinforced the dependency between the direction of information and mind, human's behavior. Information has become power over man's psyche. From a communicative tool Mass Media has changed into an independent social and political power and a part of social and political process. The expression "the forth power" is more and more often used without inverted commas together with a new term "mediacracy" coming into use.

Also, this stage of the development of Mass Media coincided with a unique period in the development of Russia and the whole world as well. Both the country and the world are in the state of transformation, in the state of new social order, new system of global economy, new system of international and cross-confessional relations. This formation of the new is as always accompanied by different crises, which is making the role of Mass Media even more prominent and requires of it new qualities and new functions. The most significant of which is facilitating 
the overcoming of crises, preventing international discord escalate, forming social tolerance, without which civil peace is impossible.

In Privolzhskiy federal region the examples of positive practice of harmonisation of international relations may be observed, which was underlined in the final resolution of the International Conference (Volzhskiy forum) "Intercultural dialogue and cross confessional cooperation", which took part in Nizhniy Novgorod in September, 2006 during Russian chairmanship in the European Council. A very important role in this process is played by Mass Media. About 7,000 newspapers and magazines, among which 6\% are published in 11 languages of the peoples of Russia, are issued in Privolzhskiy federal region, where all traditional world-wide confessions can be found and where three world-wide cultures are deeply intertwined, they being Russian culture, the culture of Turkic peoples and Finno-Ugric culture. It is also significant, that the above mentioned languages are represented not only by those of major ethnoses but also by that part of the inhabitants of the region who constitute ethnical minorities. Thus, in the republics of Mordovia, Mariy Al and Udmurtia some periodicals are issued in the Tatar language. Periodicals in Tatar, Chuvash and Mordvinian are also issued in Nizhniy Novgorod and Kirov regions. In the republics of Tatarstan, Bashkortostan and in Permskiy territory there are some periodicals issued in Chuvash, too.

In the republic of Udmurtia 17 periodicals are published in the Udmurt language. The top of the rating belongs to the newspaper "Udmurt Dunne", which is one of the first national periodicals of Udmurt people and has the status of an official body of the Government and State Council of the Republic. In the republics of Mariy Al and Mordovia radio broadcasting in the Mari, Erzya and Moksha languages is developing actively.

In the republic of Chuvashia the newspaper "Khipar" is the most popular kind of Mass Media in the Chuvash language. In the republic of Mordovia the most popular periodicals are "Chilisema" ("Sunrise"), "Moksha", "Syatko" ("Sparkle") and some others.

The activity of Privolzhkiy Finno-Ugric center in Saransk city and its periodicals "Finno-Ugric Newspaper" (chief editor professor Mishanin), the magazine "Our Home is Tatarstan" (chief editor S.K. Djaksibaev) and a radio channel "Mariy All - radio" (director A.N. Kurmuzakov) are well-known not only in the region or in Russia but also abroad.

\section{Discussion}

Let us keep in mind, however, that speaking about common tendencies in Mass Media development, it is important to mention that the coverage of international relations in it is not always "bright and sunny" but very often controversial. Modern journalism is a multisided phenomenon which includes political and social press, social and cultural press, and also corporate, glamour or "yellow" press and others. In the situation of making press more commercial-oriented a lot of periodicals have lost their cultural and educational function over-concentrating on relaxation function.

Thus, having such a great enlightenment potential and possibilities of wide and almost immediate influence on public, press, most unfortunately, does not always use these opportunities for the welfare of people, spreading low cultural standards, using the language of "hostility", aggravating xenophobia. According to the institute of ethnology and anthropology of RAS among the acute ethnical topics of Russian Media are the problems of social and cultural development of ethnoses, cross-ethnical and cross-confessional interaction, the problems of ethnical crime in Russia, the coverage of acute cross-ethnic conflicts and uncovering of different forms of ethnical extremism.

Moreover a tendency is being observed that accents and ways to cover ethno cultural and ethno political topics in regional and federal press are rather different. That is way informational space, which builds tolerance and intolerance, is very important to analyze.

The analyses of several regional and federal periodicals, published in the period of autumn and winter of 2010-2011, was carried out by the chair of journalism of Lobachevsky State University.

The main objectives of content analysis were studying qualitative and quantitative markers of the representation of ethno-cultural and ethno-political themes; the analysis of genre variety, of the stylistics and contexts in which the material on the problems of harmonization of international relations are presented; evaluating editorial policy in reference to international relation problematic.

The autumn and the winter of 2010-2011 were remarkable for the well-known events on the Manezhnaya Square in Moskow and for the sharpening of migrofobia in society. We have carried out the content analyses of the publications of this period on pages of magazines "Ogonyek" and "Our home is Tatarstan". 
"Ogonyek" is a famous public weekly illustrated magazine. The founder of "Ogonyek" is a closed joint-stock company "Komersant". Its type rage is 54 and its circulation in the studied period was 62000 copies.

"Our Home is Tatarstan" is a public quarterly enlightenment magazine published in Russian. The founder is the Assembly of peoples of Tatarstan, its type rage is 90 , and the circulation is 10000 copies.

The main objectives of ethno political discourse of the magazine "Our Home is Tatarstan" are the problems of relations between nationalities that are present in Tatarstan, migration problems, relations and dialogue of nationalities on an intercultural level. The most prominent titles are "Tatarstan - Azerbaijan: the New Bridge of Friendship", "Extremism shall not Pass!", "The History of Tatarstan is the History of Friendship of Peoples", "Migrants have become more law obedient", "Guests from Vietnam" (Morozov \& Filina, 2010). The magazine does not avoid discussing acute ethno confessional subjects but does it without affectation; sensibly trying to find what unites peoples and does not separate them.

The analyses of publications in "Ogonyek", however, shows the accentuated attention on describing negative tendencies of "forced coexistence" of different nationalities, a proof to that being the article by Morozov V. and Filina O. "A City without Incomers" (Prilepin, 2010), devoted to the situation in Hotkov, a town near Moscow all guest workers were cast out from. In the article the following expressions are used: "white city", "ethnical cleaning". Such famous journalists and writers as Pavel Sheremet and Zahar Prilepin, whose styles are sharp and harsh, are also published in the magazine. Speculating on the events on Manezhnaya Square in his article "Common Blood" Z. Prilepin summarizes that "Every organ is ready to devour another, not realizing that common blood will be spit" (Volkova \& Tikhomirov, 2010). In another article "Example to catch" it is said that "a lot of migrants from third world countries have resurrected terminal diseases long passed" (Gubin, 2010). In the article "A Mosque in Fire" aggravating stereotypes is taking place: "Muslims are alien, incomprehensible, dark, frightening". To the question in a survey "What worries Moscow citizens?" which is supplied, $42 \%$ of responders answered that it is traffic jams, $27 \%$ answered that it is incomers. Most typical titles in the magazine "Ogonyek" for the studied period are "A Mosque in Fire", "Merry Sieg Heil to you, too", "Ghost Mosques", "Common Blood", "The Year of Revelation".

Taking into consideration that today in the centre of attention of Mass Media are topics that never used to be the subject of public discussion, the role of corporate journalism in the coverage of such a tender topic as international relations in modern society is really important to mention (Avralev \& Efimova, 2014). And it is on "how our word will be responded to..." that international and cross confessional agreement in society will depend (Thurman \& Efimova, 2014).

Therefore, it is not without a reason that among the tasks of informational sphere in the Strategy of national policy of the Russian Federation the necessity of monitoring press and internet-media is underlined (Avralev \& Efimova, 2013). The purpose of it is to ban publications aimed at igniting national and confessional discord; to organize regular educational seminars for journalists on the subjects of civil unity and integrity, international and cross confessional relations, ethno cultural development of peoples of the Russian Federation; to organize and to carry out competitions for Mass Media on the best publication devoted to the subjects of international and cross confessional interaction (Avralev \& Efimova, 2013).

A balanced well-thought over position of the representatives of journalist community on the questions of international and cross confessional interaction is a very important factor of establishing international and cross confessional accord.

\section{Conclusion}

Following the tradition of intercultural dialogue in Mass Media is a very important factor of developing tolerance in society.

One of the objections in the sphere of information is monitoring Press and Digital Media no to let out publications aimed at igniting national and religious conflicts.

A carefully thought over and balanced attitude of the representatives of journalist profession in covering the questions of international and intercultural reference is very acute for establishing international and cross confessional unity.

The system of Mass Media is a mirror of social relations. So if dysfunctional elements appear in society they cannot but appear in Mass Media as well. Therefore the correlation of dysfunction in society itself is required. 
The assistance of scientific society is required in organizing regular educational seminars for journalists in questions of civil unity and integration, international and cross confessional relations, ethno cultural development of peoples.

\section{References}

Avralev, N., \& Efimova, I. (2013a). The Role of the International University Network Organizations in the Innovative Development of Russia. Middle-East Journal of Scientific Research, 14(10), 1277-1291.

Avralev, N., \& Efimova, I. (2013b). University Rankings as a Tool to Enhance Competitiveness, Clustering and Transnational Governance of Higher Education in the Context of Globalization. Middle-East Journal of Scientific Research, 16(3), 357-361.

Avralev, N., \& Efimova, I. (2014). Global university rankings as indicators of the implementation of the integration process and competitive tool in the context of globalization of higher education. Life Sci J., 11(10), 648-652.

Broun, W. (2006). Regulating aversion. Tolerance in the Age of Identity and Empire. Princeton and Oxford: Prinseton University Press.

Cottle, S. (2010). Ethnic Minorities and the Media: Changing Cultural Boundaries. Buchingham: Open University Press.

Gubin, D. (2010). A Mosque in Fire. Ogonyek magazine, 40(5149).

Lazarsfeld, P. F. (2010). Some Remarks on the Role of Mass Media in So-called Tolerance Propaganda. Journal of Social Issues, 3(3), 17-25. http://dx.doi.org/10.1111/j.1540-4560.1947.tb02209.x

Malkova, V. K., \& Tishkov, V. A. (2007). Ethnicity and Tolerance in Mass Media (p. 348). Moscow, IEA RAS.

Mass Media in public sphere. The Materials of International theoretical and practical conference "Journalism 2010". (2011). Lomonosov State University of Moscow.

Morozov, V., \& Filina, O. (2010). A city without incomers. Ogonyek magazine, 46(5155), 30-32.

Prilepin, Z. (2010). Common blood. Ogonyek magazine, 50(5159), 18-19.

Seow, T. L. (2005). Predicting tolerance of Journalistic Deception. Journal of Mass Media Ethics, 20, 24-42

The Present of the RF decree of 12.19.2012 N 1666 "To the strategy of state national policy of the Russian federation for the period up to 2025 "

Thurman, P. W., \& Efimova, I. (2014). Use of rankings to improve global competitiveness of Russian's higher education institutions and technology exports. Life Sci J, 11(11), 285-289.

Tolerance as a Factor of Counteraction against Xenophobia: Managing risks in the Society of Risk. (2011). Moscow, Nauka.

Volkova, O., \& Tikhomirov, V. (2010). An Example to Catch. Ogonyek magazine, 40(5149), 36-38.

White, C., Julie D., \& Newcomber, P. (2012). The impact of media reliance on the role of perceived threat in predicting tolerance of Muslim cultural practice. Journal of Applied Social Psychology, 42, 3051-3082. http://dx.doi.org/10.1111/j.1559-1816.2012.00973.x

\section{Copyrights}

Copyright for this article is retained by the author(s), with first publication rights granted to the journal.

This is an open-access article distributed under the terms and conditions of the Creative Commons Attribution license (http://creativecommons.org/licenses/by/3.0/). 